\title{
Nominee for US top doc grilled on political pressure
}

The post of US surgeon general, the nation's top medical authority, has long been highly politicized. The man seeking to be the next incumbent is finding himself on the front lines of the conflict between scientific evidence and public opinion over issues such as embryonic stem cell research and homosexuality.

James Holsinger, a Duke University-trained scientist whom the Bush administration has nominated as the next surgeon general, opposes direct-to-consumer advertising of drugs and, in 2002, vigorously fought an effort to criminalize stem cell research in Kentucky.

But Holsinger told a Congressional panel on 12 July that he also believes in President Bush's stem cell policy — which limits federal funding to research using stem cell lines derived before August 2001.

"I am in favor of doing stem cell research," Holsinger said. "We are doing that effectively."

The hearing came two days after three former surgeons general testified in Congress that they had been politically pressured while in office.

Most dramatically, Richard Carmona, the surgeon general from 2002 to 2006, said that he had repeatedly been compelled by senior administration officials to silence his views and to suppress reports on issues including emergency contraception, sex education and stem cell research. Carmona also testified that he had been ordered to mention President Bush three times on every page of his speeches.

The surgeon general's office has a history of facing fire for its unpopular stands. The Reagan administration fought C. Everett Koop's attempts to publicize the AIDS crisis. Joycelyn Elders, the first surgeon general under the Clinton administration, was forced to resign after she said that masturbation is normal and should perhaps be taught at schools. Her successor David Satcher testified that the Clinton administration had blocked his report on the benefits of needle exchange programs.

But the blatant interference described by Carmona, on the heels of similar allegations from several other agencies, may have at last moved Congress into action.

Democratic senator Edward Kennedy has introduced a bill meant to depoliticize the surgeon general's office by giving it an independent budget and by requiring the nominee to be drawn from a short list prepared by the Institute of Medicine.

In the meantime, Holsinger has faced stiff criticism from several members of the Senate committee that will decide whether to bring his nomination to the Senate floor for confirmation. In particular, they focused on a 1991 paper that Holsinger wrote for the United Methodist

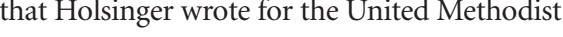

Church on "The Pathophysiology of Male Homosexuality."

"The Office of the Surgeon General has become a morass of shameful political manipulation and distortion of science," said Kennedy, the committee's chair. Holsinger's history, Kennedy went on, brought him little assurance that things would improve.

“Dr. Holsinger's paper cherry-picks and misuses data to support his thesis that homosexuality is unhealthy and unnatural," Kennedy said. "This blatant misuse of science gravely concerns me."

Holsinger replied that the paper was written for a lay audience and did not purport to meet the standards of scientific papers published in the literature. "It does not represent where I am today," he added.

Holsinger's critics include the HIV Medicine Association, one of scores of groups that wrote to Kennedy opposing the nomination.

"If he's presented with scientific evidence that abstinence-only programs don't work, will he continue to support them?" asks Dan Kuritzkes, the group's chair and director of AIDS research at Brigham and Women's Hospital in Boston.

A vote on Holsinger's nomination has not yet been scheduled, but it is unlikely to occur before Congress's August recess.

Meredith Wadman, Washington, DC

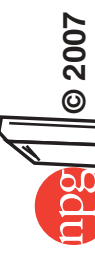

